\title{
Professional satisfaction of nursing workers from a service of hematology-oncology
}

Satisfação profissional de trabalhadores de enfermagem de um serviço de hemato-oncologia

Bruna Xavier Morais ${ }^{1}$, Cecília Mariane Pinheiro Pedro ${ }^{1}$, Graziele de Lima Dalmolin ${ }^{1}$, Augusto Maciel da Silva ${ }^{1}$

Objective: to evaluate the level of professional satisfaction of nursing staff from a service of hematologyoncology. Methods: a cross-sectional study was carried out with 46 nursing workers from a service of hematology-oncology. A questionnaire was used with sociodemographic, labor data and the instrument of Professional Satisfaction Index. Descriptive statistics were used to analyze the data. Results: the level of job satisfaction found was 11.17, considered low. The most important component among workers in terms of professional satisfaction was interaction (2.96), followed by autonomy (2.93), and the least important was professional status (1.62). Conclusion: it was observed a low index of professional satisfaction of the nursing staff of the service of hematology-oncology. The components interaction and autonomy were considered the most important for job satisfaction.

Descriptors: Job Satisfaction; Nursing; Occupational Health.

Objetivo: avaliar o nível de satisfação profissional de trabalhadores de enfermagem de um serviço de hematooncologia. Métodos: estudo transversal, realizado com 46 trabalhadores de enfermagem de um serviço de hemato-oncologia. Utilizou-se questionário com dados sociodemográficos, laborais e o instrumento Índice de Satisfação Profissional. Para análise dos dados foi utilizada estatística descritiva. Resultados: o nível de satisfação profissional encontrado foi de 11,17, considerado baixo. 0 componente mais importante entre os trabalhadores no que se refere à satisfação profissional foi a interação $(2,96)$, seguida da autonomia $(2,93)$, e o menos importante foi o status profissional $(1,62)$. Conclusão: observou-se baixo índice de satisfação profissional dos trabalhadores de enfermagem do serviço de hemato-oncologia. Os componentes interação e autonomia foram considerados os mais importantes para a satisfação profissional.

Descritores: Satisfação no Emprego; Enfermagem; Saúde do Trabalhador.

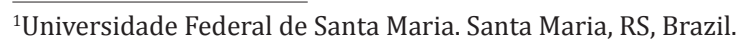




\section{Introduction}

The work process has changed in the last decades, due to the transformations resulting from globalization. Through these, productivity and competitiveness in the labor market were increased. Accordingly, the demands on workers were intensified, seeking greater qualification, pace and workload. This scenario may result in decreased professional satisfaction, which may directly interfere with their health/illness process $^{(1)}$.

Professional satisfaction is defined by the affective state that individuals present through work experiences $^{(2)}$, and the higher the satisfaction factors, the greater the commitment of the worker to the provision of qualified assistance. Some aspects are considered sources of job satisfaction, such as adequate salary, autonomy in decision making, relationships with colleagues in the profession and the possibility of personal and professional growth ${ }^{(3)}$. It also involves aspects of infrastructure and working conditions, such as availability of material resources, necessary for the satisfactory performance of activities ${ }^{(4)}$.

Thus, it is considered that the professional satisfaction can depend on several factors, among them, the nature of the work and the experience of each worker in labor activities. In the occupational context of the nurse, the daily exposure to the excessive routine of activities is highlighted, which are characterized by intense stress situations ${ }^{(5)}$. In the hospital environment, in particular, nursing work can be considered complex, since professionals are responsible for promoting the care of patients, along with the other members of the nursing and health team. These, from the work environment and interpersonal relationships, are subject to develop feelings of pleasure and joy, as well as dissatisfaction and suffering, and can lead to physical or psychic exhaustion ${ }^{(6)}$.

Emphasis is given to workers working in the sector of hematology-oncology, an area that involves specificity, complexity and exigency. They daily experience patients who are exposed to prolonged and ag- gressive treatments, subject to side effects, mutilating surgeries, high emotional impairment, suffering, pain and, sometimes, death ${ }^{(7-8)}$. Other situations, such as dealing with the distress and anguish of family members of patients, lack of agility in the accomplishment of examinations and availability of medications by the health network, coexist with the rotation of professionals in the work sector, unpreparedness of teammates (lack of knowledge about the area) and lack of recognition and appreciation of work by the institution are also important sources of professional dissatisfaction $^{(9)}$.

In view of the above, the study presented as a research question: what is the level of professional satisfaction of nursing workers in a service of hematology-oncology? Therefore, the objective was to evaluate the level of professional satisfaction of nursing workers from a service of hematology-oncology.

\section{Methods}

This cross-sectional study was carried out with nursing workers from the hematology-oncology department of a university hospital in the central region of Rio Grande do Sul, Brazil. The service includes the chemotherapy and radiotherapy outpatient clinics, a pediatric oncology unit and a bone marrow transplant center, in which 52 nursing workers worked.

Non-probabilistic sampling was used for convenience, but to reduce the occurrence of possible biases, a minimum sample was calculated by means of a finite sampling formula ${ }^{(10)}$, resulting in a minimum number of 45 participants.

As an inclusion criterion, participants should have been working for at least 30 days in the industry. Because of holidays or licenses in the period of data collection these professionals were excluded. Thus, 46 nursing workers, 23 nurses, 18 nursing technicians and five nursing assistants participated in the study.

Data collection took place from December 2014 to March 2015, by members of the research group previously trained by the researcher in charge. Nursing 
workers were invited to respond to the questionnaire during work shifts, and the research instrument was delivered along two routes of the Informed Consent Term, scheduling the time for the return. The search attempt was performed up to three times.

Sociodemographic data (sex, age, marital status and children) and labor data (education, profession, weekly workload and work shift) were used, as well as the Professional Satisfaction Index instrument, constructed and validated in a North American context ${ }^{(11)}$, adapted to the Brazilian scenario, being used in several studies in this scenario ${ }^{(4-5)}$, aiming at verifying the level of satisfaction of nurses in relation to the work components and to identify the relative importance attributed to them: autonomy, interaction, professional status, work requirements, organizational norms, and remuneration ${ }^{(4)}$.

The Professional Satisfaction Index is a self-administered instrument, composed of two parts (A and B). The first (part A) consists of a list of comparisons with 15 pairs of components ${ }^{(4-5)}$. It allows measuring the relative importance of each component, attributed by the research participant, making possible the understanding of their expectations ${ }^{(11)}$. The second (part B), called the Attitudes Scale, consists of 44 statements covering the six components of job satisfaction, organized on a seven-point Likert scale, varying from disagreeing entirely ${ }^{(1)}$ and agreeing entirely ${ }^{(7)}$. This part measures how well the nursing worker is satisfied in relation to each of the six components ${ }^{(11)}$.

For the analysis of part A (Pareto Comparisons), first, a frequency matrix was developed, relating how many times each component was chosen in relation to the others. Afterwards, this was transformed into a standard of proportion, and in turn, into a matrix of Z-scores, to convert the proportions into standard deviations. Correction of the Z-score occurred by adding a correction factor $(+2.5)$, with the purpose of eliminating the negative values ${ }^{(4)}$.

Regarding the analysis of part B (Attitude Scale), initially, the items were grouped according to each component, and the scores of the questions with po- sitive statements were inverted. After that, the Total Component Score was calculated. Then, it has the value divided by the total number of items of each component, giving rise to the Average Scores of Components ${ }^{(4)}$.

The Adjusted Component Score (weighting coefficient $\mathrm{x}$ component average score) was then calculated. At the end, the adjusted scores of each component were summed and divided by the number of components, resulting in the Professional Satisfaction Index, which can vary from 0.9 to 37.1 , in a positive direction $^{(5)}$.

The data were included in the Excel $\AA$ program, with double typing. Subsequently, for the analysis of the data, we used descriptive statistics using the Predictive Analitycs Software program, the Statistical Package for the Social Sciences (PASW Statistic $囚$ ) version 18.0 for Windows and the statistical program $\mathrm{R}$ version 3.0.2.

The study respected the formal requirements contained in the national and international norms regulating research involving human beings.

\section{Results}

Most of the participants were female (95.7\%), with an average age of 38.57 years and standard deviation $(\mathrm{SD}=8.24)$, married or living with a partner (76.1\%) and had only one children (41.3\%). Regarding the labor characteristics, nurses predominated (50.0\%), with specialization (65.2\%), average weekly working hours of 31.7 hours (SD=10.86) and night workers (30.0\%).

Regarding the professional satisfaction of nursing workers, we identified an index of 11.17 , considered low, according to analysis of parts A and B of the instrument, as observed in the sequence.

In part $\mathrm{A}$, according to Table 1 , it was verified that the component selected more frequently by the participants, that is, considered as more important, was the autonomy in relation to the professional status. 
Table 1 - Matrix of absolute frequencies of the answers obtained in the paired comparisons of the Professional Satisfaction Index of nursing workers from the service of hematology-oncology $(n=46)$

\begin{tabular}{|c|c|c|c|c|c|c|}
\hline \multirow[b]{2}{*}{ Less important } & \multicolumn{6}{|c|}{ More importante } \\
\hline & Remuneration & Autonomy & $\begin{array}{c}\text { Requirements at } \\
\text { work }\end{array}$ & $\begin{array}{l}\text { Professional } \\
\text { status }\end{array}$ & $\begin{array}{l}\text { Organizational } \\
\text { norms }\end{array}$ & Interaction \\
\hline Remuneration & - & 33 & 25 & 13 & 22 & 28 \\
\hline Autonomy & 13 & - & 18 & 6 & 17 & 26 \\
\hline Requirements at work & 21 & 28 & - & 7 & 12 & 26 \\
\hline Professional status & 33 & 40 & 39 & - & 34 & 39 \\
\hline Organizational norms & 24 & 29 & 34 & 12 & - & 34 \\
\hline Interaction & 18 & 20 & 20 & 7 & 12 & - \\
\hline
\end{tabular}

To obtain the weighting coefficient of each component of job satisfaction, the proportions described in Table 1 were converted into standard deviations.
Thus, the proportion matrix was converted into a Z-score matrix, using the correction factor +2.5 , in order to eliminate the negative values (Table 2).

Table 2 - Z-score matrix of the answers obtained by the nursing staff of the service of hematology-oncology, with weighting coefficient $(\mathrm{n}=46)$

\begin{tabular}{|c|c|c|c|c|c|c|}
\hline \multirow[b]{2}{*}{ Less important } & \multicolumn{6}{|c|}{ More important } \\
\hline & Remuneration & Autonomy & $\begin{array}{c}\text { Requirements at } \\
\text { work }\end{array}$ & $\begin{array}{c}\text { Professional } \\
\text { status }\end{array}$ & $\begin{array}{c}\text { Organizational } \\
\text { norms }\end{array}$ & Interaction \\
\hline Remuneration & - & 0.574 & 0.108 & -0.574 & -0.055 & 0.277 \\
\hline Autonomy & -0.574 & - & -0.277 & -1.126 & -0.332 & 0.164 \\
\hline Requirements at work & -0.108 & 0.277 & - & -1.028 & -0.64 & 0.164 \\
\hline Organizational norms & 0.055 & 0.332 & 0.64 & -0.64 & - & 0.64 \\
\hline Interaction & -0.277 & -0.164 & -0.164 & -1.028 & -0.64 & - \\
\hline Sum & -0.33 & 2.145 & 1.335 & -4.396 & -1.027 & 2.273 \\
\hline Average & -0.066 & 0.429 & 0.267 & -0.879 & -0.205 & 0.455 \\
\hline Correction Factor & 2.5 & 2.5 & 2.5 & 2.5 & 2.5 & 2.5 \\
\hline Component weighting coefficient & 2.43 & 2.93 & 2.77 & 1.62 & 2.3 & 2.96 \\
\hline
\end{tabular}

The weighting coefficient, according to Table 2, demonstrates the order of importance of each component of the Professional Satisfaction Index given by the nursing staff of the hematology-oncology department surveyed. The most important component among workers in terms of professional satisfaction was interaction (2.96), followed by autonomy (2.93), and the least important was professional status (1.62).

The results of the A and B parts were conver- gent, since it was observed, for example, in the interaction component, the participants stated $(76.1 \%)$ that the doctors cooperated with the nursing team, as well as reported (93.5\%) and help among the nursing staff. Regarding the autonomy, the majority (80.4\%) of the workers affirmed that they had sufficient participation in the planning of the assistance. This fact, it is shown that the components were important for professional satisfaction among the workers surveyed. 
Table 3 shows the weighting coefficient, adjusted, total and average scores, of the Occupational Satisfaction Index among hematology-oncology nursing workers.

Table 3 - Weighting coefficient, Total, Average and Adjusted Scores of the Professional Satisfaction Index among hematology-oncology nursing workers $(n=46)$

\begin{tabular}{lcccc}
\hline & \multicolumn{2}{c}{ Weighting } & \multicolumn{3}{c}{ Total score } & \multicolumn{2}{c}{ Average Score } & $\begin{array}{c}\text { Adjusted } \\
\text { coefficient } \\
\text { (part A) }\end{array}$ & (part B) & (part B) & (AxB) \\
\hline Autonomy & 2.93 & 36.48 & 4.56 & 13.36 \\
Interaction & 2.96 & 46.91 & 4.69 & 13.88 \\
Professional status & 1.62 & 38.41 & 5.49 & 8.89 \\
Requirements at work & 2.77 & 26.74 & 4.46 & 12.35 \\
Organizational norms & 2.30 & 25.57 & 3.65 & 8.40 \\
Remuneration & 2.43 & 25.11 & 4.19 & 10.18 \\
Sum & - & - & - & 67.06 \\
$\begin{array}{l}\text { Occupational satisfaction } \\
\text { index }\end{array}$ & - & - & - & 11.17 \\
\hline
\end{tabular}

It was verified that the nursing workers who worked in the service of hematology-oncology researched had greater professional satisfaction with the interaction between the workers, followed by the autonomy in the accomplishment of the labor activities.

\section{Discussion}

It was considered as a limitation of the study the fact that the data collection occurred during vacations and new hiring, so that the participants may not have experienced situations involving all components evaluated on job satisfaction.

Nursing work on hematology-oncology is characterized as care that involves, in addition to the care practices, peculiar situations, such as the specificity of the treatments used and the presence of sensitized patients, with greater limitations. The therapeutic methods in this area involve from drug therapies to interventional methods, such as surgeries, or means that require a greater technological apparatus. With this, professionals are required to be aware, attentive and committed to providing care, which implies a diversity of tasks to be developed in the day to day occupational. Besides the particularities of the area, there are also organizational problems of work, such as conflicts between staff, lack of control of activities and work overload ${ }^{(12)}$.

The index of professional satisfaction identified is similar to other studies performed in the Brazilian scenario, such as among nursing workers working in an oncology hospital, who presented an index of $10.01^{(13)}$, nurses working in intensive care units presented indices between $8.62^{(5)}$ and $10.95^{(14)}$, and nursing technicians from the same sector $11.01^{(5)}$. It is observed, therefore, that the findings of the studies are approximate and demonstrate low professional satisfaction of nursing workers.

Nursing work in this area can lead to situations of suffering or illness, as well as implications for professional satisfaction ${ }^{(8)}$. In this perspective, the findings of this evaluation among nursing workers pointed out that the interaction component was considered the most important, followed by autonomy. Similar evaluation among nurses in the oncology sector pointed to autonomy (3.41) as the most important component for professional satisfaction, followed by remuneration (3.06) and interaction (2.80) $)^{(13)}$.

Interaction in nursing work involves interpersonal relationships, cooperation and formal communication in work activities, being an important factor for professional satisfaction, since these are determinants to develop qualified care in different health settings. It should be noted once again that service of hematology-oncology demand complexity and demands on care, involve aggressive treatments, side effects, feelings of fear and insecurity on the part of patients ${ }^{(7)}$, which demonstrates the importance of interaction and interpersonal relationship in this environment.

A comparative study among Brazilian and Portuguese professionals from the oncology sector observed that teamwork, especially between nursing 
and physicians, was considered a reason for professional satisfaction. It is emphasized that the interaction among professionals, that is, support and efficient communication among team members can assist in patient care and safety, as well as promoting job satisfaction $^{(8)}$.

Nursing professionals, at a University Hospital, point out that the interaction among members of the nursing team, promoted by the joint and collaborative performance of care is related to cooperation in nursing work, constituting a fundamental instrument in the articulation of nursing actions ${ }^{(15)}$.

Regarding the autonomy component, it was observed in an international study that this was considered the most important component for professional satisfaction in nursing workers ${ }^{(16)}$. Nurses from a Basic Health Unit attribute the lowest importance to the autonomy component, evaluating professional status as the second most important aspect for professional satisfaction $^{(17) \text {. }}$

In hematology-oncology, autonomy at work is considered an important point in the management of care, which involves, in addition to nursing techniques and practices, health education and research activities (theoretical deepening). Professional autonomy in nursing is exercised by the professional when, based on his pro-activity, uses scientific knowledge, skills and competencies in the practice of care and decision-making. This is found in the care practices provided to people who need the knowledge and specific skill of this profession. Therefore, it is necessary to base the assistance on scientific knowledge and its own legislation. It involves positioning and leadership in the work, which allows establishing a bond of trust between the professional and society ${ }^{(18-19)}$.

Finally, similar to that found among nursing workers in an intensive care unit ${ }^{(5)}$, professional status proved to be the component that generates less satisfaction among workers. It should be noted that this component can be related to the feeling generated by the low professional appreciation, recognition for the work developed, financial recognition, accumulation of professional activities and low expectation of professional growth among nursing workers, consequently, which may result in a decrease in professional satisfaction $^{(5,17)}$.

However, when compared to the other components, professional status was the one that had the least influence on satisfaction, demonstrating that the workers surveyed were more satisfied with elements that directly involved nursing care, rather than recognition and external valuation. As contributions of the study, it is emphasized that the findings can be a tool for managers of health institutions in the formulation of resources and actions for the prevention of occupational sickness, health promotion of workers and improvement of the quality of care

In view of this, it is important to note the importance of conducting new studies on satisfaction in nursing work, especially regarding the identification of aspects that may contribute to low satisfaction rates, as well as the search for strategies for greater satisfaction.

\section{Conclusion}

It was observed low index of professional satisfaction of the nursing workers of the service of hematology-oncology. The interaction and autonomy components were considered the most important for professional satisfaction.

\section{Collaborations}

Silva AM contributed in the conception and design or analysis and interpretation of the data. Morais BX and Pedro CMP contributed in writing the article and critically reviewing the intellectual content. Dalmolin GL contributed to the final approval of the version to be published. 


\section{References}

1. Antunes R, Praun L. A sociedade dos adoecimentos no trabalho. Serv Soc Soc. 2015; (123):407-27. doi: http://dx.doi.org/10.1590/0101-6628.030

2. Paglione NL, Vannuchi MTO, Tenani MNF, Pissinati PSC. Professional satisfaction of the nursing team of the surgical center in a medium complexity public hospital. Rev Enferm UFPE on line [Internet]. 2016 [cited 2017 Sep 22]; 10(3):10807. Available from: http://www.revista.ufpe.br/ revistaenfermagem/index.php/revista/article/ view/7130/pdf_9872

3. João ALS, Alves CP, Silva C, Diogo F, Ferreira ND. Validação de uma Escala de Satisfação dos Enfermeiros com o trabalho para a população portuguesa. Rev Enf Ref. 2017; (12):117-30. doi: https://doi.org/10.12707/RIV16066

4. Tenani MNF, Vannuchi MTO, Haddad MCL, Matsuda LM, Pissinat PSC. Satisfação profissional dos trabalhadores de enfermagem recémadmitidos em hospital público. Rev Min Enferm. 2014; 18(3):585-91. doi: http://www.dx.doi. org/10.5935/1415-2762.20140043

5. Versa GLGS, Matsuda LM. Satisfação profissional da equipe de enfermagem intensivista de um hospital de ensino. Rev Enferm UERJ [Internet]. 2014 [citado 2017 out. 30]; 22(3):409-15. Disponível em: http://www.e-publicacoes. uerj.br/index.php/enfermagemuerj/article/ view/5765/10511

6. Morais MP, Martins JT, Galdino MJQ Robazzi MLCC, Trevisan GS. Satisfação no trabalho de enfermeiros em um hospital universitário. Rev Enferm UFSM. 2016; 6(1):1-9. doi: http://dx.doi. org/10.5902/2179769217766

7. Umann J, Silva RM, Benavente SBT, Guido LA. The impact of coping strategies on the intensity of stress on hemato-oncology nurses. Rev Gaúcha Enferm. 2014; 35(3):103-10. doi: http://dx.doi. org/10.1590/1983-1447.2014.03.44642
8. Bordignon M, Monteiro MI, Mai S, Martins MFSV, Rech CRA, Trindade LL. Oncology nursing professionals' job satisfaction and dissatisfaction in Brazil and Portugal. Texto Contexto Enferm. 2015; 24(4):925-33. doi: http://dx.doi. org/10.1590/0104-0707201500004650014

9. Bordignon M, Ferraz L, Beck CLC, Amestoy SC, Trindade LL. (Dis)satisfaction of health professionals who work with oncology. Rev Rene. 2015; 16(3):398-406. doi: http://dx.doi. org/10.15253/2175-6783.2015000300013

10. Sampieri HR, Collado CF, Lucio MPB. Metodologia de pesquisa. Porto Alegre: Penso; 2013.

11. Ahmad N, Oranye NO, Danilov A. Rasch analysis of Stamps's Index of Work Satisfaction in nursing population. Nurs Open. 2016; 4(1):32-40. doi: http://dx.doi.org/10.1002/nop2.61

12. Umann J, Silva RM, Benetti ERR, Guido LA. Stress and Coping among nurses of hemato-oncologic units. Rev Rene [Internet]. 2013 [cited 2017 Aug. 29]; 14(4):783-90. Available from: http://www. redalyc.org/pdf/3240/324028459015.pdf

13. Silva VR, Velasque LS, Tonini T. Job satisfaction in an oncology nursing team. Rev Bras Enferm. 2017; 70(5):1040-7. doi: http://dx.doi. org/10.1590/0034-7167-2016-0422

14. Oliveira EM, Barbosa RL, Andolhe R, Eiras FRC, Padilha KG. Nursing practice environment and work satisfaction in critical units. Rev Bras Enferm. 2017; 70(1):73-80. doi: http://dx.doi. org/10.1590/0034-7167-2016-0211

15. Rothebarth AP, Cesário JB, Lima LPS, Ribeiro MRR. O trabalho em equipe na enfermagem: da cooperação ao conflito. Rev Gest Saúde [Internet]. 2016 [citado 2017 ago. 29]; 7(2):521-34. Disponível em: http://periodicos.unb.br/index. php/rgs/article/view/22037/15732

16. O'Keeffe AP, Corry M, Moser DC. Measuring job satisfaction of advanced nurse practitioners and advanced midwife practitioners in the Republic of Ireland: a survey. J Nurs Manag. 2015; 23(1):10717. doi: http://dx.doi.org/10.1111/jonm.12096 
17. Pinto IC, Panobianco CSMM, Zacharias FCM, Bulgarelli AF, Carneiro TSG, Gomide MFS, et al. Analysis of job satisfaction of the nursing staff of a primary health care unit. Rev Gaúcha Enferm. 2014; 35(4):20-7. doi: http://dx.doi. org/10.1590/1983-1447.2014.04.45491

18. Hey AP, Caveião C, Montezeli JH, Cardoso FS, Pruner JA, Silva TT. Perception of nurses about their autonomy in prevention of pneumonia associated with mechanical ventilation. Rev Enferm UFPE on line [Internet]. 2015 [cited 2017 sep. 22]; 9(Supl. 7):9062-8. Available from: https://periodicos. ufpe.br/revistas/revistaenfermagem/article/ view/10698/11765
19. Bellaguarda MLR, Padilha MI, Pereira Neto AF, Pires D, Peres MAA. Reflection on the legitimacy of the autonomy at nursing in the field of the health professions in the light of Eliot Freidson's ideas. Esc Anna Nery. 2013; 17(2):369-74. doi: http://dx.doi. org/10.1590/S1414-81452013000200023 